\title{
TUNNELING, GOVERNANCE, DAN PERFORMANCE SEBUAH STUDI BIBLIOMETRIK
}

\author{
Siti Arifah ${ }^{1)^{*}}$, Agung Nur Probohudono ${ }^{2)}$, Rahmawati ${ }^{3)}$, Setianingtyas Honggowati ${ }^{4}$ \\ ${ }^{1}$ Fakultas Ekonomi, Universitas Tidar \\ email: sitiarifah@untidar.ac.id \\ ${ }^{1}$ Fakultas Ekonomi dan Bisnis, Universitas Sebelas Maret \\ email: sitiarifah@,student.uns.ac.id \\ ${ }^{2}$ Fakultas Ekonomi dan Bisnis, Universitas Sebelas Maret \\ email: anprobohudono@staff.uns.ac.id \\ ${ }^{3}$ Fakultas Ekonomi dan Bisnis, Universitas Sebelas Maret \\ email: rahmaw2005@yahoo.com \\ ${ }^{4}$ Fakultas Ekonomi dan Bisnis, Universitas Sebelas Maret \\ email: setianingtyas_27@yahoo.co.id
}

\begin{abstract}
This study aims to determine research trends with the topik of tunneling, governance and performance with several accompanying variables. The method used is a bibliometric study, with Vosviewer analysis. This study uses data on the publication of research articles published in science directin the period 2010 - 2020. The conclusion that can be drawn from this study is that research publications related to tunneling, governance, and performance have experienced significant fluctuations. Many published in various journals, especially in $Q 1$ and Q2. The related variables lead to developments that are more complex and in accordance with developments in world economic conditions. The country that dominates as the object of research is China with a very striking difference compared to other countries. It is hoped that this research can provide implications in the form of further directions and opportunities in conducting research related to tunneling, governance, and performance.
\end{abstract}

Keywords: tunneling; propping; governance; performance

\begin{abstract}
ABSTRAK
Penelitian ini bertujuan untuk mengetahui trend penelitian dengan topik tunneling, governance dan performance dengan beberapa variabel yang menyertainya. Metode yang digunakan yakni studi bibliometrik, dengan analisa Vosviewer. Penelitian ini menggunakan data publikasi artikel penelitian yang dipublikasikan di science direct pada periode tahun 2010 - 2020. Kesimpulan yang dapat diperoleh dari penelitian ini adalah bahwa publikasi penelitian terkait tunneling, governance, dan performance mengalami fluktuasi yang cukup signifikan. Banyak dipublikasikan di berbagai jurnal, terutama pada Q1 dan Q2. Variabel yang terkait mengarah pada perkembangan yang lebih komplek dan sesuai dengan perkembangan kondisi perekonomian dunia. Negara yang mendominasi sebagai obyek penelitian adalah China dengan perbedaan yang sangat mencolok dibanding dengan Negara lain. Diharapkan penelitian ini dapat memberikan implikasi berupa arah dan peluang lebih lanjut dalam melakukan penelitian terkait tunneling, governance, dan performance.
\end{abstract}

Kata Kunci: tunneling; propping; governance; performance 


\section{PENDAHULUAN}

Tata kelola perusahaan yang baik (OECD, 2004) adalah seperangkat hubungan antara manajemen perusahaan, dewan direksi, pemegang saham, dan pemangku kepentingan lainnya. Tata Kelola Perusahaan merupakan mekanisme administrasi yang mengatur hubungan antara manajemen perusahaan, komisaris, direksi, pemegang saham, dan pemangku kepentingan lainnya. Hal ini terlihat dari pengalaman Amerika Serikat yang harus merestrukturisasi tata kelola perusahaan akibat ambruknya pasar pada tahun 1929 . Tata kelola perusahaan yang buruk diisyaratkan sebagai salah satu penyebab krisis ekonomi-politik yang dimulai pada tahun 1997 yang dampaknya adalah masih terasa sampai hari ini. Krisis keuangan saat ini di Amerika Serikat juga karena ketidaksesuaian penerapan prinsipprinsip GCG, beberapa kasus skandal keuangan seperti Enron Corp, Worldcom, Xerox, dan lain-lain yang melibatkan eksekutif puncak perusahaan menggambarkan pelaksanaan belum dikreditkan prinsip-prinsip GCG. Analisis komparatif dilakukan (Bohinc, 2010) terkait komposisi dewan di satu tier OF THE US dan dua tier di Eropa khususnya, serta distribusi kekuasaan kepada Dewan Direksi dan manajemen eksekutif. Perbedaan utama antara sistem satu tingkat dan dua tingkat adalah bahwa kekuasaan manajemen eksekutif di AS didelegasikan oleh dewan dan secara teoritis dapat diganti kapan saja, sementara kekuasaan, misalnya, Dewan Manajemen di Jerman diatur oleh hukum. dan tidak dapat diubah bahkan dengan keputusan pemegang saham tentang amandemen Anggaran. Kedua badan Dewan Pengawas dan Dewan Pengurus secara tegas dipisahkan dan dilarang untuk dirangkap.

Mekanisme tata kelola perusahaan dibangun dan pengukuran penilaian pasar untuk semua perusahaan publik di dua pasar saham di China menggunakan data dari laporan tahunan perusahaan (Bai et al., 2004; Liu \& Lu, 2007). Indeks tata kelola perusahaan dibuat untuk merangkum informasi yang terdapat dalam variabel tata kelola perusahaan, menggunakan delapan variabel untuk mengukur berbagai mekanisme tata kelola perusahaan. Ini juga memberikan panduan yang berguna bagi perusahaan untuk merancang mekanisme tata kelola perusahaan untuk meningkatkan penilaian pasar untuk menguntungkan pemegang saham dan mengurangi biaya investasi di masa depan. Tunneling cenderung dilakukan melalui penjualan ke perusahaan afiliasi dengan hak arus kas yang lebih rendah (Cho \& Lim, 2018).

Tunneling hadir dengan berbagai kondisi seperti penelitian yang dilakukan oleh Cheung, Jing, et al., 2009; Cheung, Qi, et al., 2009; Friedman et al., 2003; Lo et al., 2010; Peng et al., 2011; Ryngaert \& Thomas, 2007, 2012. Tunneling mungkin timbul dari adanya transaksi pihak terkait/RPT (Juliarto \& Tower, 2013). Sedangkan tunneling negatif (atau menopang) diperkenalkan melalui penelitian ((Bai et al., 2004; Cheung et al., 2006; Friedman et al., 2003; Peng et al., 2011). Propping umumnya dilakukan oleh pemegang saham pengendali untuk mendukung perusahaan yang mengalami kesulitan keuangan atau kebangkrutan.

Pemegang saham pengendali dapat memiliki insentif dan kemampuan untuk mengambil alih pemegang saham minoritas (Aharony et al., 2010; Bertrand 
et al., 2002; Claessens et al., 2002; Johnson et al., 2000; Lin et al., 2010). Selain itu, bukti adanya tunneling control dari pemegang saham di China (Jiang et al., 2010) melalui pinjaman antar perusahaan, yang diperkirakan puluhan miliar (RMB) dari tahun 1996 hingga 2006. Grup bisnis India menjadi lebih besar dan lebih beragam seiring dengan institusi pasar berkembang. Temuan ini bertentangan dengan prediksi dan implikasi dari semua aliran pemikiran sebelumnya tentang kelompok bisnis termasuk dari (Bertrand et al., 2002). Kelompok bisnis India terus meningkatkan intensitas pemasaran dan investasi pihak terkait teknologi seiring berkembangnya lembaga pasar. Konsep kelompok bisnis sebagai alat pengambilalihan dan sebagai pelaku utama tata kelola yang buruk di negara berkembang harus direformasi menggunakan metodologi empiris yang lebih halus yang menggabungkan analisis kegiatan strategis di seluruh perusahaan (Siegel \& Choudhury, 2012). Sementara bukti dari tahun 1997 dan 1998 krisis keuangan Asia secara luas mendukung gagasan bahwa ada propping (Friedman et al., 2003). Berdasarkan perkembangan yang telah terjadi, penelitian ini mencoba menjawab pertanyaan bagaimana perkembangan publikasi penelitian terkait dengan topik tunneling/propping, performance dan governance, serta variabel apa saja yang banyak dikaitkan dengan topik tersebut sebagai gambaran arah penelitian selanjutnya.

\section{KAJIAN LITERATUR}

Kondisi pemusatan kepemilikan atau kepemilikan keluarga, yang bertentangan dengan kepemilikan yang meluas, mendorong terjadinya 'konflik keagenan Tipe 2'. Konflik keagenan tipe 2 mengacu pada perbedaan kepentingan antara pemegang saham pengendali dan pemegang saham minoritas di suatu perusahaan. Adanya pemegang saham pengendali yang dominan mengendalikan jalannya perusahaan dapat mengurangi konflik keagenan tipe 1 karena manajemen juga dikendalikan oleh pemegang saham pengendali sehingga perbedaan kepentingan antara pemegang saham dan manajemen menjadi minimal. Namun, adanya konflik tipe 2 lembaga ini merugikan pemegang saham minoritas yang sebagian besar merupakan masyarakat umum. Secara umum, konflik keagenan tipe 2 biasanya berupa keuntungan pribadi yang diambil oleh pemegang saham pengendali yang merugikan kepentingan pemegang saham minoritas.

Bukti pengendalian pemegang saham melalui transaksi pihak berelasi dilakukan (Cheung et al., 2006) dengan menguji apakah transaksi terkait adalah tunneling atau propping dengan mengklasifikasikannya menjadi 7 kategori: (1) akuisisi aset oleh pihak berelasi, (2) penjualan aset oleh pihak terkait, (3) pertukaran aset antara perusahaan dan pemegang saham pengendali, (4) perdagangan barang dan jasa antara perusahaan dan pemegang saham pengendali, (5) pembayaran tunai, pinjaman atau jaminan oleh perusahaan kepada pemegang saham pengendali, (6) pembayaran tunai, pinjaman, atau jaminan pinjaman yang diberikan oleh pihak terkait kepada perusahaan, dan (7) pengalihan aset kepada perusahaan dari anak perusahaan yang dimiliki mayoritas dan tidak go public dimana terdapat kemungkinan merugikan pemegang saham minoritas anak perusahaan untuk kepentingan pemegang saham perusahaan. Transaksi yang terjadi pada kategori 6 dan kategori 7 akan menguntungkan perusahaan atau dikenal dengan propping. Sedangkan pada 
kategori 5 dimana terdapat pembayaran tunai oleh perusahaan kepada pihak terkait memiliki kemungkinan tunneling yang tinggi. Sedangkan kategori 1-4 adalah transfer aset atau pembelian barang dan jasa dapat berupa tunneling atau propping.

Tunneling diartikan sebagai pengalihan aset dan keuntungan dari suatu perusahaan untuk kepentingan pemegang saham mayoritas (Johnson et al., 2000). Tunneling adalah salah satu bentuk ekspropriasi. Ada dua bentuk tunneling, yaitu melalui transaksi self-dealing dengan transfer aset atau dengan meningkatkan kepemilikan tanpa transfer aset. Pengalihan aset oleh pemegang saham mayoritas dapat dilakukan dengan mengalihkan sumber daya dari perusahaan untuk keuntungannya, baik dalam bentuk transaksi ilegal yang mungkin tidak terdeteksi atau penjualan aset melalui kontrak seperti transfer pricing, jaminan pinjaman, kompensasi berlebihan kepada eksekutif, atau pengambilalihan aset. acara perusahaan. Sedangkan peningkatan kepemilikan pemegang saham mayoritas tanpa pengalihan aset dapat dilakukan melalui masalah saham dilutif, perdagangan orang dalam, pembekuan minoritas, akuisisi, atau transaksi lain yang dapat mengakibatkan kerugian bagi pemegang saham minoritas. Secara umum pemilik dan atau manajer dalam kelompok bisnis memiliki insentif yang kuat untuk mengambil sumber daya dari perusahaan anggota untuk keuntungan mereka (Bae et al., 2002; Bertrand et al., 2002; Lemmon et al., 2003), sehingga memungkinkan mereka untuk menggunakan keputusan investasi dan pembiayaan sebagai sarana untuk melakukan tindakan penyelarasan. Studi empiris (La Porta et al., 2000b, 2000a) menemukan bahwa perlindungan investor yang kuat, dalam hal ini terkait dengan masalah tunneling, terkait dengan tata kelola perusahaan yang efektif. Independensi dewan yang lebih tinggi berkorelasi negatif dengan transaksi pihak berelasi (RPT). Tata Kelola Perusahaan yang Lebih Baik secara signifikan mengurangi ukuran RPkewajiban dan sedikit mengurangi ukuran RP-aset. Adanya tata kelola yang baik diharapkan dapat mengurangi risiko perusahaan yang timbul akibat transaksi terkait (Agnihotri \& Bhattacharya, 2019; Gao \& Kling, 2008).

\section{METODE PENELITIAN}

Penelitian ini merupakan tinjauan literatur yang merupakan metode tinjauan pustaka dengan merangkum dan mengevaluasi kumpulan tulisan tentang topik tertentu (Knopf, 2006). Tinjauan literatur terstruktur digunakan untuk memetakan dan mengevaluasi sebuah literatur untuk mengetahui potensi kesenjangan penelitian dan mengetahui batasan pengetahuan (Fahimnia, Sarkis, \& Davarzani, 2015). Sedangkan analisis bibliometrik terkadang disebut juga dengan istilah scientometrics merupakan bagian dari metodologi evaluasi penelitian, dan dari berbagai literatur yang telah banyak dihasilkan, memungkinkan dilaksanakan analisis bibliometrik dengan menggunakan metode tersendiri (Ellegaard \& Wallin, 2015). Penelitian ini melakukan screening terhadap artikel yang diperoleh dari laman Science Direct yang selanjutnya akan dianalisis melalui beberapa kriteria sebagai berikut: 
Tabel 1. Data artikel yang ditemukan

\begin{tabular}{|c|c|}
\hline Kriteria & $\begin{array}{l}\text { Artikel } \\
\text { hasil } \\
\text { screening }\end{array}$ \\
\hline $\begin{array}{l}\text { Kata kunci: } \\
\text { Tunneling, Propping, Governance, } \\
\text { Performance }\end{array}$ & 181 \\
\hline $\begin{array}{l}\text { Subject area: } \\
\text { Business, Management, and } \\
\text { Accounting } \\
\text { Economics, Econometrics, and } \\
\text { Finance } \\
\text { Social Science }\end{array}$ & 142 \\
\hline Tahun: 2011 - 2021 & 111 \\
\hline Type: Research article & 104 \\
\hline $\begin{array}{l}\text { Kesesuaian pembahasan: } \\
\text { dari abstrak }\end{array}$ & 95 \\
\hline
\end{tabular}

Tabel 1 menunjukkan bahwa artikel yang diolah dalam penelitian ini adalah sebanyak 95 data. Selanjutnya terhadap 95 data tersebut dilakukan analisis bibliometrik dengan menggunakan aplikasi VOSviewer dengan analisis yang dilakukan meliputi:

- Co-occurrence analysis, digunakan untuk mengungkap topik/variabel penelitian secara statistik.

- Co-authorship analysis, digunakan untuk menemukan hubungan beberapa peneliti berdasarkan dokumen penelitian yang dihasilkan oleh peneliti.

Bibliographic analysis, digunakan untuk mengungkap bidang penelitian yang kemungkinan akan berubah dari tahun ke tahun sebagai akibat dari para peneliti yang membuat penemuan dan mengalihkan perhatian mereka ke berbagai masalah penelitian.

\section{HASIL DAN PEMBAHASAN}

Perkembangan publikasi yang dihasilkan dari penelitian tunneling, propping, governance, performance pada rentang waktu tahun 2011 sampai dengan tahun 2021 menunjukkan pergerakan yang sangat berfluktuasi. Penelitian ini mengumpulkan sebanyak 95 artikel dari laman Science Direct sesuai dengan hasil screening sesuai topik yang ditetapkan dengan sebaran sebagaimana ditunjukkan pada gambar 1 berikut:

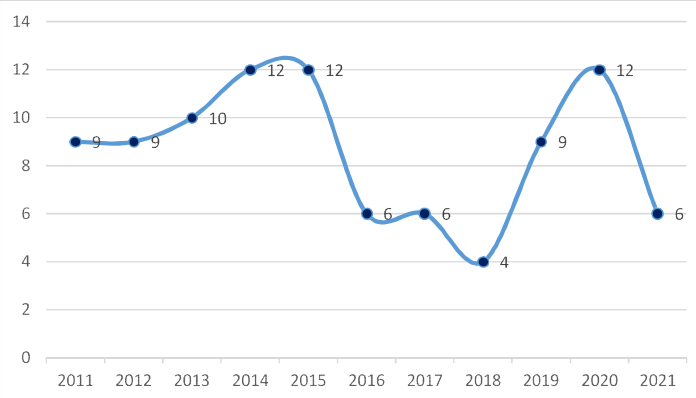

Gambar 1. Pertumbuhan Publikasi Terkait Topik Tunneling

Sebelum tahun 2015 publikasi terkait hasil penelitian mengenai topik tunneling menunjukkan adanya peningkatan, namun pada tahun 2016 - 2018 menunjukkan penurunan yang cukup tajam. Hal ini mungkin dikarenakan tidak terlalu banyak kasus yang ditemui terkait tunneling/ propping sehingga tidak menjadikan topik mengenai tunneling ini sebagai suatu ketertariakan untuk diteliti. Hal sebaliknya ditunjukkan dari publikasi sejak tahun 2019 yang menunjukkan adanya kenaikan yang signifikan. Meskipun jumlah pada tahun 2021 menunjukkan angka yang kecil, hal ini dikarenakan data publikasi yang diperoleh pada tahun 2021 hanya terbatas sampai dengan waktu penelitian ini dilakukan yaitu pada pertengahan tahun 2021, sehingga masih sangat membuka kemungkinan untuk jumlah ini bertambah lagi, dengan pertimbangan pada akhir tahun terdapat banyak publikasi yang akan dilakukan oleh berbagai publisher. Selanutnya berikut ini disajikan sebaran 15 jurnal tertinggi yang mempublikasikan 
hasil penelitian terkait Tunneling, Propping, Governance, dan Performance.

Tabel 2. Lima Belas Tertinggi Publisher yang Mempublikasikan Hasil Penelitian Terkait Tunneling, Propping, Governance, dan Performance

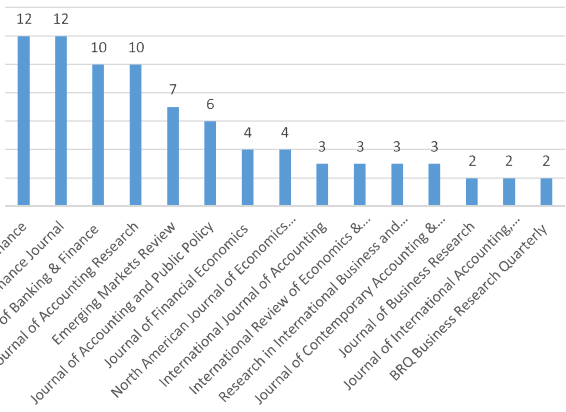

Sumber: Data diolah penulis (2021)

Tabel 2 menunjukkan bahwa publikasi mengenai topik Tunneling, Propping, Governance, dan Performance terpublikasi dengan sebaran yang baik, dalam arti tidak didominasi oleh publisher tertentu saja. Hal ini menunjukkan bahwa topik Tunneling di bidang ekonomidan keuangan merupakan topik yang dapat diterima di hampir semua publisher yang artinya merupakan topik yang sudah umum untuk dipahami dan layak untuk dipertimbangkan dalam penerbitan. Gambar 2 berikut menampilkan sebaran publikasi terkait topik penelitian ini pada Quartile Scopus.

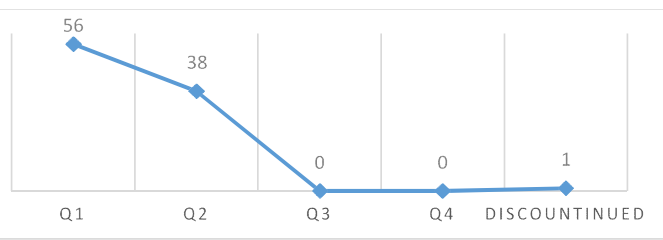

Gambar 2. Sebaran Publikasi Terkait Topoik Penelitian ini di Quartile Scopus

Gambar 2 menggambarkan bahwa ternyata publikasi terkait tunneling, propping, governance, dan performance berhasil menempati quartile bergengsi di Scopus yaitu di Q1 dan Q2. Hal demikian berarti bahwa topik terkait dengan penelitian ini mendapatkan perhatian dan kepercayaan yang sangat baik untuk dipublikasikan di Jurnal-jurnal yang berkualifikasi sangat baik. Adapun variabel-variabel lain yang digunakan dalam penelitian-penelitian terkait dengan tunneling, propping, governance, dan performance digambarkan dalam Gambar 3 berikut:

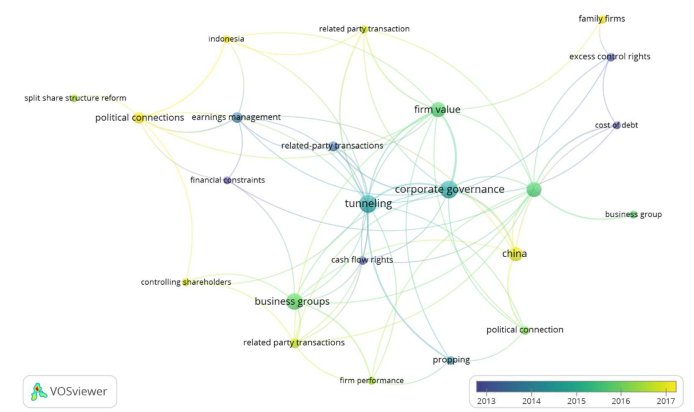

Gambar 3. Variabel Terkait Topik Tunneling

Gambar 3 memberikan gambaran tentang variabel apa saja yang sering muncul dikaitkan dengan tunneling, propping, governance, dan performance. Semakin besar lingkaran yang ditunjukkan pada masing-masing variabel di Gambar 3 menunjukkan bahwa variabel tersebut semakin sering digunakan atau semakin sering muncul. Tabel 3 berikut memberikan gambaran mengenai kuantifikasi masing-masing variabel: 
Tabel 3. Jumlah dan Link Antar Variabel

\begin{tabular}{lcccc}
\hline \multicolumn{1}{c}{ Variabel } & Cluster & $\begin{array}{c}\text { Total } \\
\text { link }\end{array}$ & Occurrences & Avg. pub. Year \\
\hline business groups & 1 & 11 & 13 & 2015.77 \\
controlling shareholders & 1 & 4 & 3 & 2016.67 \\
firm performance & 1 & 6 & 3 & 2016.33 \\
propping & 1 & 6 & 4 & 2014 \\
related party transactions & 1 & 9 & 5 & 2016.6 \\
business group & 2 & 2 & 3 & 2015.67 \\
cost of debt & 2 & 5 & 3 & 2012.33 \\
excess control rights & 2 & 4 & 4 & 2013.25 \\
family firms & 2 & 2 & 4 & 2017.5 \\
ownership structure & 2 & 14 & 11 & 2015.64 \\
earnings management & 3 & 8 & 6 & 2013.67 \\
financial constraints & 3 & 4 & 3 & 2012.67 \\
political connections & 3 & 9 & 7 & 2017 \\
split share structure reform & 3 & 1 & 3 & 2016.33 \\
political connection & 4 & 6 & 4 & 2016 \\
cash flow rights & 5 & 6 & 4 & 2013.25 \\
related-party transactions & 5 & 7 & 5 & 2013.6 \\
firm value & 6 & 18 & 11 & 2015.64 \\
related party transaction & 6 & 7 & 3 & 2016.67 \\
\hline
\end{tabular}

Sumber: Data diolah peneliti 2021

Tabel 3 menunjukkan variabel apa saja yang sering dikaitkan dengan topik penelitian ini. Angka pada kolom klaster menunjukkan bahwa variabel tersebut sering muncul dikaitkan dengan variabelvariabel lain pada klaster yang sama, meski tidak menutup kemungkinan variabel tersebut dikaitkan dengan variabel yang lain pada kelompok klaster yang lain. Angka pada total link menunjukkan seberapa sering variabel tersebut dikaitkan dengan variabel yang lain, seperti variabel firm value, business group, dan ownership structure. Angka pada kolom occurences menujukkan seberapa banyak variabel tersebut muncul pada publikasi. Sedangkan kolom Avg.pub.Year menunjukkan waktu kapan variabel tersebut menjadi trend atau sering muncul pada publikasi. Dari tabel 3 di atas menunjukkan bahwa banyak variabel yang muncul yang sudah diteliti, dikaitkan dengan topil tunneling, propping, governance, \& performance, namun masih banyak variabel lain yang belum terdaftar pada tabel tersebut. Hal demikian berarti masih banyak variabel yang belum diteliti yang dikaitkan dengan topik penelitian ini, sehingga memberikan kesempatan kepada para penulis untuk mengeksplore lebih lanjut variabel-variabel yang belum terdaftar pada tabel 3. Gambar 4 berikut ini memberikan gambaran mengenai paraauthor yang sering mempublikasikan hasil penelitian terkait dengan topik penelitian ini, yang selanjutnya dapat digunakan sebagai bahan untuk referensi.

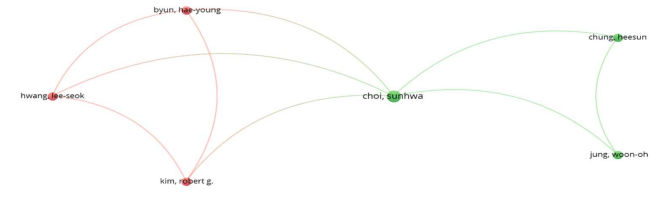

\section{Gambar 4. Jaring Author dengan Publikasi Terkai Topik Penelitian Ini}

Gambar 4 menunjukkan bahwa beberapa penulis berpartner dengan penulis lain terkait dalam melakukan publikasi. Semakin besar lingkaran yang ditunjukkan pada masing-masing nama author berarti semakin sering penulis tersebut melakukan publikasi, seperti Sunhwa Choi. Semakin sering seorang author muncul dalam publikasi dengan topik yang sama, dapat diartikan bahwa penulis yang bersangkutan semakin memahami topik yang ditulisnya tersebut. Selanjutnya, semakin memahami seorang author, berarti bahwa author tersebut semakin layak untuk dijadikan referensi untuk penelitian selanjutnya dengan topik yang berkaitan. Gambar 5 berikut nenunjukkan sebaran obyek penelitian terkait tunneling, propping, governance dan performance. 


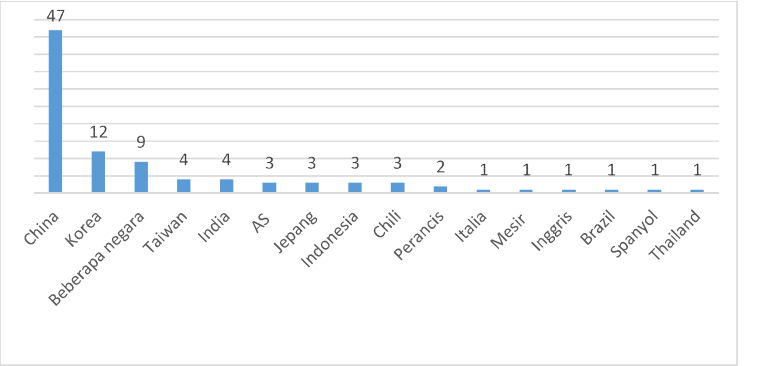

Gambar 5. Grafik Sebaran Obyek Penelitian

Gambar 5 menunjukkan bahwa China menjadi objek tertinggi dalam penelitian terkait tunneling, propping, governance, dan performance, dan selisih jumlahnya menunjukkan perbedaan yang signifikan. Dengan demikian dapat diartikan bahwa topik terkait tunneling, propping, governance, dan performance lebih berkembang di China, dan baru selanjutnya berkembang ke Negara lain. Lebih berkembangnya topik ini di China dapat dimungkinkan karena lebih kompleksnya masalah yang dihadapi dunia bisnis di China dan/atau lebih cermatnya peneliti yang bersangkutan dalam menggali masalah untuk dikembangkan dalam bentuk penelitian.

\section{KESIMPULAN DAN SARAN}

Perkembangan penelitian terkait tunneling, propping, governance, dan performance selama 10 tahun belakangan menunjukkan fluktuasi yang signifikan. Hal ini mungkin terjadi karena permasalahan yang ada di dunia bisnis secara nyata, yang kadang masalah terkait tunneling ini muncul dan menjadi trend penelitian. Hasil penelitian ini menunjukkan bahwa publikasi terkait topik tunneling ini menyebar di beberapa jurnal yang berkualitas pada quartile Scopus terbaik. Hasil penelitian juga menunjukkan perkembangan variabel tunneling, propping, governance, dan performance, yang dikaitkan dengan beberapa variabel tertentu dan sering muncul seperti firm value, business group, dan ownership structure. Penulis yang sering mempublikasikan hasil penelitiannya terkait topik penelitian ini diantaranya adalah Sunhwa Choi, dan obyek yang paling sering diamati adalah Negara China.

Keterbatasan dalam penelitian ini adalah bahwa hasil analisis VOSviewer tidak menggambarkan link dengan nilai sangat kecil sehingga hasil penelitian ini tidak bisa memberikan gambaran yang jelas terkait perkembangan terkini penelitian dengan topik tunneling, propping, governance, dan performance untuk tahun-tahun terbaru. Namun demikian penelitian ini diharapkan dapat berimplikasi untuk menjadi lebih mudah dan lebih tepatnya arah penelitian tentang tunneling, propping, governance, dan performance di masa depan. Tidak hanya melakukan penelitian dengan variabel yang sudah banyak terekplorasi, layaknya melakukan penelitian ulang saja, namun dapat mengeksplorasi variabel-variabel lain yang lebih tepat sesuai perkembangan situasi dan kondisi terkini, sehingga lebih memperkaya khasanah keilmuan terkait tunneling, propping, governance, dan performance.

\section{DAFTAR PUSTAKA}

Agnihotri, A., \& Bhattacharya, S. (2019). Internationalization, related party transactions, and firm ownership structure: Empirical evidence from an emerging market. Research in International Business and Finance, 48 , 340-352. https://doi.org/https://doi.org/10.1016 /j.ribaf.2019.02.004

Aharony, J., Wang, J., \& Yuan, H. (2010). Tunneling as an incentive for earnings management during the IPO process in China. Journal of Accounting and Public Policy, 29(1), $1-26$.

https://doi.org/https://doi.org/10.1016 /j.jaccpubpol.2009.10.003

Bae, K., Kang, J., \& Kim, J. (2002). 
Tunneling or Value Added? Evidence from Mergers by Korean. THE JOURNAL OF FINANCE, LVII(6), 2695-2740.

Bai, C. E., Liu, Q., \& Song, F. M. (2004). Bad News is Good News: Propping and Tunnelling Evidence from China (Issue 852).

Bertrand, M., Mehta, P., \& Mullainathan, S. (2002). Ferreting Out Tunneling: An Application to Indian Business Groups. The Quarterly Journal of Economics, February.

Bohinc, Rado, 2000. Abstract of Choosing between the US Single Board or the European Two-Tier Board: A Brief Comparative Corporate Governance Analysis. [online]. dalam http://papers.ssrn .com/sol3/papers.cfm?abstract id $=22$ 1969 [diakses 20 Januari 2011].

Cheung, Y. L., Jing, L., Lu, T., Rau, P. R., \& Stouraitis, A. (2009). Tunneling and propping up: An analysis of related party transactions by Chinese listed companies is. Pacific-Basin Finance Journal, 17(3), 372-393. https://doi.org/10.1016/j.pacfin.2008. 10.001

Cheung, Y. L., Qi, Y., Rau, P. R., \& Stouraitis, A. (2009). Buy high, sell low: How listed firms price asset transfers in related party transactions. Journal of Banking and Finance, 33(5), 914-924. https://doi.org/10.1016/j.jbankfin.200 8.10.002

Cheung, Y. L., Rau, P. R., \& Stouraitis, A. (2006). Tunneling, propping, and expropriation: evidence from connected party transactions in Hong Kong. Journal of Financial Economics, 82(2), 343-386. https://doi.org/10.1016/j.jfineco.2004. 08.012

Cho, S., \& Lim, K. M. (2018). Tunneling by Related-party Transactions: Evidence from Korean Conglomerates. Asian Economic Journal, 32(2), 147-164. https://doi.org/10.1111/asej.12146

Claessens, S., Djankov, S., Fan, J. P. H., \& Lang, L. H. P. (2002). Disentangling the incentive and entrenchment effects of large shareholdings. Journal of Finance, 57(6), 27412771. https://doi.org/10.1111/15406261.00511

Ellegaard, O., \& Wallin, J. A. (2015). The bibliometric analysis of scholarly production: How great is the impact?. Scientometrics, 105(3), 1809-1831.

Fahimnia, B., Tang, C. S., Davarzani, H., \& Sarkis, J. (2015). Quantitative models for managing supply chain risks: A review. European journal of operational research, 247(1), 1-15.

Friedman, E., Johnson, S., \& Mitton, T. (2003). Propping and tunneling. Journal of Comparative Economics, $31(4)$, 732-750. https://doi.org/10.1016/j.jce.2003.08. 004

Gao, L., \& Kling, G. (2008). Corporate governance and tunneling: Empirical evidence from China tr. PacificBasin Finance Journal, 16, 591-605. https://doi.org/10.1016/j.pacfin.2007. 09.001

Jiang, G., Lee, C. M. C., \& Yue, H. (2010). Tunneling through intercorporate loans: The China experience. Journal of Financial Economics, 98(1), 1-20. https://doi.org/10.1016/j.jfineco.2010. 05.002

Johnson, S., La Porta, R., Lopez, F., \& Shleifer, A. (2000). Tunneling. The Near Crash, 90(02), 22-27.

Juliarto, A., \& Tower, G. (2013). Managerial Ownership Influencing Tunnelling Behaviour. Australasian Accounting, Business and Finance Journal, 7(2), 25-46. https://doi.org/10.14453/aabfj.v7i2.3

Knopf, J. W. (2006). Doing a literature review. PS: Political Science \& Politics, 39(1), 127-132.

La Porta, R., Lopez-de-Silanes, F., 
Shleifer, A., \& Vishny, R. (2000a). Agency Problems and Dividend Policies Around the World. Tho Journal of Finance, IV(1).

La Porta, R., Lopez-de-Silanes, F., Shleifer, A., \& Vishny, R. (2000b). Investor Protection and Corporate Governance. Journal of Financial Economics, 58, 3-27.

Lemmon, M. L., Lins, K., \& Davidson, W. (2003). Ownership Structure, Corporate Governance, and Firm Value : Evidence from the East Asian Financial Crisis. The Journal of Finance, 393, 1-39.

Lin, Y., Chiou, J., \& Chen, Y. (2010). Ownership Structure and Dividend Preference Evidence from China's Privatized State-Owned Enterprises. Emerging Markets Finance \& Trade, 46(1), 56-74. https://doi.org/10.2753/REE1540496X460106

Liu, Q., \& Lu, Z. (Joe). (2007). Corporate governance and earnings management in the Chinese listed companies: A tunneling perspective. Journal of Corporate Finance, 13(5), 881-906. https://doi.org/10.1016/j.jcorpfin.200 7.07.003

Lo, A. W. Y., Wong, R. M. K., \& Firth, M. (2010). Can corporate governance deter management from manipulating earnings? Evidence from relatedparty sales transactions in China. Journal of Corporate Finance, 16(2), 225-235.

https://doi.org/10.1016/j.jcorpfin.200

9.11.002

OECD. (2004). OECD Principles of Corporate Governance 2004.

Peng, W. Q., Wei, K. C. J., \& Yang, Z. (2011). Tunneling or propping: Evidence from connected transactions in China. Journal of Corporate Finance, 17(2), 306-325. https://doi.org/10.1016/j.jcorpfin.201 0.08 .002

Ryngaert, M., \& Thomas, S. (2007). Related Party Transaction; Ownership
Structure; Tunneling; Corporate Governance. SSRN Electronic Journal.

Ryngaert, M., \& Thomas, S. (2012). Not All Related Party Transactions ( RPTs ) Are the Same: Ex Ante Versus Ex Post RPTs. Journal of Accounting Research, 50(3), 845882. https://doi.org/10.1111/j.1475679X.2012.00437.x

Siegel, J., \& Choudhury, P. (2012). A reexamination of tunneling and business groups: New data and new methods. Review of Financial Studies, 25(6), 1763-1798. https://doi.org/10.1093/rfs/hhs008 